\title{
O NIEKTÓRYCH MEANDRACH W RUSYCYSTYCE ZACHODNIOEUROPEJSKIEJ
}

\author{
LABYRINTHS OF RUSSIAN STUDIES IN WESTERN EUROPE
}

\author{
WŁADYSŁAW FIGARSKI
}

\begin{abstract}
The article focuses on the complex process of development and the actual state of contemporary Russian studies in selected countries of Western Europe. The author describes this hard and thorny path of development which, like a maze, is intricate and ambiguous as well as full of difficulties and obstacles, and he analyzes the condition of Russian studies in England, France, Italy and Spain.
\end{abstract}

Władysław Figarski, Uniwersytet Warszawski, Warszawa - Polska.

Zainteresowanie Rosją ze strony świata zachodniego ma wielowiekową tradycję, przy czym czasy Piotra I (1672-1725) uznaje się za przełomowe. Wówczas to jej kontakty z krajami zachodnimi znacznie się ożywiły. Pionierami byli przede wszystkim kupcy prowadzący handel wymienny między Rusią/Rosją i Europą Zachodnią. Ich szlaki handlowe prowadziły najpierw przez takie miasta jak: Nowgorod (Nowogród Wielki), Psków, Witebsk, Włodzimierz, Suzdal, Moskwę, Kijów, a następnie obejmowały kolejne skupiska miejskie. Do pewnego stopnia za pionierów można uznać także dyplomatów, którzy, z natury rzeczy, musieli władać językami obcymi, w tym i językiem rosyjskim.

Piotr I, korzystając ze wzorów zachodnioeuropejskich, a zwłaszcza niemieckich, uczynił zacofaną Rosję państwem nowoczesnym, jak na tamte czasy. Kolejni władcy, a zwłaszcza Katarzyna II, za cenę trudną do wyobrażenia, dopełnili reszty. Rosja stała się państwem silnym, wywierającym coraz większy wpływ na losy innych państw i narodów, a zwłaszcza sąsiadów. Ekspansjonizm rosyjski, a potem radziecki, jakiego doświadczali ci ostatni, obejmował wszystkie sfery życia, nie wyłączając języka agresorów i zaborców w jednym. Był to jeden z najbardziej istotnych czynników decydujących o coraz szerszym zasięgu języka, literatury i kultury rosyjskiej poza granicami Rosji. Ale nie był to czynnik jedyny. Chronologicznie rzecz ujmując, potrzebę znajomości języka rosyjskiego wyznaczały najpierw handel i dyplomacja, dalej (w. XIX) wielka, jedyna w swoim rodzaju, bogactwie i pięknie literatura i kultura rosyjska, sama Rosja z całym swym 
bogactwem materialnym i duchowym, Rosja (ZSRR) jako mocarstwo w skali światowej, jej (jego) osiągnięcia naukowo-techniczne i wreszcie sam język rosyjski jako narzędzie komunikacji.

Oczy i umysły ludzi wykształconych i przedsiębiorczych ze świata zachodniego zwracały się w stronę Rosji coraz częściej, wywołując w sposób naturalny szerokie zainteresowanie tym krajem $\mathrm{w}$ jego różnych dziedzinach.

W orbicie owego zainteresowania znalazły się, jak się rzekło, także język i literatura rosyjska oraz szeroko rozumiana tamtejsza kultura. Początkowo były to, jak można przypuszczać, przypadki jednostkowe, odnoszące się do podróżników, ludzi ciekawych świata i prawdziwych pasjonatów, ale z czasem ich liczba stale rosła, aż do pojawienia się ośrodków badawczych, zajmujących się początkowo językiem staroruskim/staro-cerkiewno-słowiańskim i tekstami $\mathrm{w}$ tych językach pisanymi, a następnie językoznawstwem, literaturoznawstwem i kulturoznawstwem rosyjskim w rozumieniu współczesnym. Poza samą Rosją, gdzie na przestrzeni stuleci niezwykle dynamicznie rozwijały się badania naukowe nad językiem rosyjskim, gdzie postęp $\mathrm{w}$ dziedzinie rusycystyki wyznaczali uczeni tej miary, co M. Łomonosow (Русская грамматика, 1775), F. Busłajew, autor pierwszej rosyjskiej gramatyki historycznеј (Историческая грамматика русского языка, 1858), W. Dal (Толковый словарь живого великорусского языка, 1863), J. Grot, autor fundamentalnej pracy o ortografii rosyjskiej (Русское правописание, 1885; ponad 20 wydań), F. Fortunatow, twórca słynnej moskiewskiej szkoły lingwistycznej - językoznawstwa porównawczo-historycznego i autor fundamentalnych prac w tej dziedzinie, A. Szachmatow, leksykograf, badacz rosyjskiego języka literackiego i jego historii (История русского языка, 1911; Синтаксис русского языка, 1925), D. Uszakow, l. Szczerba, W. Winogradow, J. Baudouin de Courtenay, N. Kruszewski, R. Awanesow, S. Ożegow, dalej N. Szanski, E. Bryzgunowa, A. Leontiew i wielu, wielu innych, aktywnością odznaczały się $\mathrm{w}$ tej dziedzinie ośrodki akademickie krajów zachodnioeuropejskich, a zwłaszcza uniwersytety angielskie, francuskie, niemieckie, włoskie i inne. Apogeum owego zainteresowania przypada na drugą połowę wieku XIX, kiedy to literatura rosyjska stała się przedmiotem poważnych badań naukowych na Zachodzie.

W najstarszych uniwersytetach europejskich pojawiali się uczeni - badacze języków i kultur słowiańskich, prawdziwi pasjonaci szeroko rozumianej slawistyki, co z czasem prowadziło do powstawania katedr skupiających większe zespoły znawców i propagatorów literatur słowiańskich i języków Słowian. Wiedza przez nich przekazywana docierała do coraz szerszych kręgów studentów i słuchaczy, a pasja badawcza mistrzów nierzadko znajdowała wielu naśladowców wśród ich uczniów. Tak rodziła się slawistyka, najpierw w krajach słowiańskich, a w ślad za tym slawistyka 
zachodnioeuropejska. Powstawały katedry języków, literatur i kultur słowiańskich we Francji, w Niemczech, w Anglii, we Włoszech. Wyrazistym i bliskim nam przykładem niech będzie Katedra Literatury Słowiańskiej w Collége de France, którą objął A. Mickiewicz w 1840 roku. Wykłady naszego wieszcza były czymś bardzo znaczącym w przybliżeniu dorobku kulturowego i prezentowanych przez Słowian wartości ogólnych. Słuchacze mogli poznać historię Polski i dzieje Rosji, konflikty polsko-rosyjskie, a nade wszystko znaczenie Słowian, ich kultury i literatury dla cywilizacji Zachodu. To był początek zainteresowania kulturą słowiańską we Francji.

Rusycystyka europejska, jako byt samoistny, rodziła się bardzo powoli, najczęściej w ramach slawistyki, jako istotny jej składnik. Swój najbujniejszy rozkwit przeżywa od wieku dwudziestego, od drugiej jego połowy, a fundamentem tego rozkwitu była - jak zawsze - wysoka pozycja już nie Rosji, a Związku Radzieckiego - mocarstwa w skali światowej, jego osiągnięcia naukowe, techniczne, gospodarcze i militarne, wysoka pozycja literatury rosyjskiej i radzieckiej, kultura i sztuka rosyjska oraz sami Rosjanie. I niezależnie od tego, jak bardzo rozkwit ów związany był z ideologią komunistyczną byłego Związku Radzieckiego, skala i zasięg badań naukowych obejmujących literaturoznawstwo, językoznawstwo i kulturoznawstwo rosyjskie, a także glottodydaktykę rusycystyczną nie tylko w krajach bloku sowieckiego, lub będących pod jego przemożnym wpływem, ale i w krajach wolnych i demokratycznych Europy Zachodniej, była i jest do dziś, chociaż przy nieco odmiennych uwarunkowaniach, naprawdę imponująca.

Ale nie był to i nie jest do dziś proces pozbawiony wielu osobliwości, złożoności, subtelności, sekretów, zawiłości - słowem: meandrów najrozmaitszych. Warto więc nieco bliżej przyjrzeć się temu procesowi, przynajmniej $\mathrm{w}$ niektórych krajach Zachodu, $\mathrm{z}$ akcentem na ważniejsze subtelności, konteksty owego rozwoju i opisać je choćby w największym skrócie.

Zacznijmy od tego, że w wieku osiemnastym i na początku dziewiętnastego na zachodzie Europy panowało wśród filologów dość powszechne przekonanie o znikomym znaczeniu języka rosyjskiego jako przedmiotu badań, ponieważ był to, jak sądzono, język prostego ludu, język bez bogatych tradycji, a więc mało atrakcyjny w porównaniu z językami zachodnioeuropejskimi. A fakt, że arystokracja rosyjska, utrzymująca ścisłe kontakty z Europą Zachodnią, posługiwała się wyłącznie językiem francuskim lub niemieckim, nigdy rosyjskim, przekonanie to umacniał i czynił prawie pewnikiem. Poza tą „wadą" były jeszcze inne, na przykład ta, że był to język trudny, często niemożliwy do opanowania w mowie i piśmie, zupełnie nieprzydatny, co, niestety, w innej już skali i z mniejszą częstotliwością, obowiązuje po dziś dzień. W Niemczech na przykład, w niektórych 
krajach związkowych, jeszcze do drugiej połowy wieku dwudziestego język rosyjski był, co prawda, zaliczany do grupy języków obcych, których można było nauczać, ale ze względu na jego strukturę i formy gramatyczne postrzegany był jako język bliski łacinie i grece. Był więc traktowany jako element kształcenia formalnego, na równi z tymi językami, nie zaś jako narzędzie komunikacji.

Owa osobliwość pozostawiła trwały ślad w poglądach na metodykę nauczania tego języka i jej zastosowaniach na długie lata w wielu krajach. A konsekwencją był m.in. fakt, że najdłużej nauczano go metodą gramatyczno-tłumaczeniową, kładąc nacisk na werbalny przekaz reguł gramatycznych, zapamiętywanie paradygmatów i wszelkich wyjątków, czytanie i tłumaczenie sztucznie preparowanych tekstów, „wkuwanie” całych ciągów słówek i zwrotów.

Rusycystyka jest, jak już wspomniano, częścią slawistyki, dodajmy, częścią istotną, a w Europie Zachodniej częścią dominującą. Obejmuje dyscypliny zajmujące się językoznawstwem rosyjskim, literaturą rosyjską, językiem rosyjskim jako narzędziem komunikacji, lingwodydaktyką rusycystyczną, kulturą mowy, socjologią języka, realioznawstwem rosyjskim itd. Taki jest stan obecny, ale zakres badań rusycystycznych, czyli pola badawcze rusycystyki, zmieniały się na przestrzeni lat. Początkowo skromne badania historycznoliterackie, analizy językoznawcze z czasem nie tylko się wzbogacały, ale także inspirowały pojawianie się coraz to nowych dyscyplin, będących teraz istotnymi składnikami rusycystyki współczesnej. Tak działo się i nadal dzieje się wszędzie, także w krajach Zachodu.

Efekty tych badań były i są prezentowane w licznych publikacjach, na konferencjach naukowych, kongresach, sesjach i w pracach o charakterze metodologicznym. Już dawno wyszły one z zacisznych gabinetów uczonych, stając się swoistym ruchem naukowym na wielką skalę. Jest to istotna, ale nie jedyna, osobliwość współczesnej rusycystyki. W odbiorze społecznym, $\mathrm{w}$ odróżnieniu od wybitnych nawet dzieł historycznoliterackich czy językoznawczych, powstających, jak się rzekło, w zacisznych gabinetach uczonych, liczy się popularność języka A. Puszkina w danym kraju, liczą się sposoby i rezultaty jego nauczania. Niech więc ten ostatni aspekt stanie się motywem wiodącym dalszych rozważań.

Popularność danego języka, jego umiędzynarodowienie, w stopniu najwyższym zależy od potencjału materialnego i intelektualnego narodu, który jest jego użytkownikiem, potencjału ekonomicznego, naukowego, kulturalnego, politycznego i społecznego kraju przez ten naród zamieszkałego. Zależy także od relacji tego kraju i narodu z innymi państwami i narodami, a zwłaszcza z sąsiadami. Na gruncie tych przesłanek kształtuje się w świadomości ludzi obraz zewnętrzny danego kraju i narodu. Jest to proces na ogół długotrwały, obejmuje dziesiątki lat, a nawet stulecia, ma więc 
charakter historyczny. Jego rezultaty jawią się w postaci indywidualnych odczuć i ocen wyrażanych najczęściej opiniami: „stosunek pozytywny", ",stosunek negatywny", "stosunek obojętny", "stosunek wrogi" itp., co wcale nie znaczy, że tenże obraz zewnętrzny danego kraju będzie obiektywny, adekwatny do stanu rzeczywistego lub będzie zakłamany i niesprawiedliwy.

Zewnętrzny obraz Rosji, podkreślmy to raz jeszcze, zmieniał się na przestrzeni dziejów jej historycznego rozwoju. Pod tym względem Rosja nigdy nie była przysłowiowym monolitem. O dynamice jej rozwoju i zmienności decydowały i decydują po dziś dzień istotne w odbiorze społecznym procesy i zdarzenia o charakterze politycznym, społecznym, ekonomicznym, kulturalnym i, niestety, coraz częściej militarnym. Są to bardzo istotne, aby nie rzec decydujące, stymulatory takiego a nie innego obrazu Rosji, samych Rosjan i języka rosyjskiego na arenie międzynarodowej. To z nich wyrastały skrajne i zarazem przeciwstawne opinie i sądy uogólniające z podtekstem radziecko-rosyjskim w rodzaju: "kapitalizm - socjalizm (komunizm)”, „cywilizacja - barbarzyństwo”, "kapitalizm z ludzką twarzą - dziki kapitalizm" (czytaj: kapitalizm europejski, amerykański - kapitalizm rosyjski), „wolność - zniewolenie”, "demokracja - autokratyzm”, „postęp - zacofanie”, "wysoka kultura - niska kultura” (czytaj: kultura europejska - „ruska” kultura), „Europa Zachodnia - Rosja” (czytaj: my jesteśmy z Europy Zachodniej, oni z Rosji, tzn. my jesteśmy "lepsi", oni "gorsi" od nas) i tak dalej. Od takich i im podobnych sądów już tylko krok do najrozmaitszych, często prymitywnych, stereotypów nie mających nic wspólnego z rzeczywistym obrazem Rosji, narodu rosyjskiego, jego kultury, języka, obyczajów i życia duchowego.

Stereotyp jest specyficznym obrazem czegoś, obrazem wykształconym w naszym umyśle nie na drodze własnego doświadczenia, lecz założonym z góry mniemaniu, przy czym obraz tak powstały bywa najczęściej wyjaskrawiony, przesadny, uproszczony, a często zdeformowany. Każda stereotypowa postawa charakteryzuje się znacznym ładunkiem emocjonalnym - pozytywnym lub negatywnym, co czyni ją odporną na wszelkie zmiany. Nosicielami stereotypów bywają najczęściej grupy lub warstwy społeczne, a nawet całe narody. Są przekazywane z pokolenia na pokolenie i bezkrytycznie przejmowane. Bywa, że stają się źródłem albo przybierają postać najrozmaitszych uprzedzeń, w których ładunek negatywnych emocji jest jeszcze większy, niż ma to miejsce w stereotypach. Stereotypy, w odniesięniu do każdego narodu, w sposób oczywisty zakłócają proces upowszechniania jego kultury i języka. Dotyczy to także języka i kultury rosyjskiej w krajach Zachodu. Tak więc stereotypy to kolejna przywara, z którą wciąż boryka się współczesna rusycystyka.

Rosja i inne kraje słowiańskie na nadmiar stereotypów w Europie Zachodniej narzekać nie mogą, choć przyznać trzeba, że odwzajemniają się 
z równą "wdzięcznością". Jednakże wraz z rozwojem kontaktów międzyludzkich i tak zwanej komunikacji międzykulturowej oraz środków masowego przekazu, a przede wszystkim Internetu, pewna refleksja jednak następuje i ogólny obraz zasygnalizowanego zjawiska, zarówno po jednej, jak i po drugiej stronie, jakby tracił na ostrości. Jest to również zasługa licznej rzeszy nauczycieli-rusycystów, szeroko rozumianej rusycystyki i jej osiągnięć, zarówno w warstwie badawczej, jak i aplikacyjnej.

Spośród krajów zachodnioeuropejskich najbogatsze tradycje rusycystyka posiada w Anglii, Francji, w Niemczech, we Włoszech, w Holandii, w Austrii, nieco skromniejsze w Hiszpanii, Finlandii, Szwecji, Norwegii, Danii i w innych krajach Zachodu. Była to reakcja na rozwój tej dziedziny nauki w krajach słowiańskich - m.in. w Czechach, w Polsce, a przede wszystkim w Rosji. Wszędzie jednak jej początki były bardzo trudne. W Anglii na przykład, gdzie tradycje akademickie należą do najstarszych na naszym kontynencie, gdzie zaplecze naukowo-intelektualne i szacunek dla wiedzy były zawsze znakomite, gdzie pierwsza gramatyka rosyjska w wersji łacińskiej została wydana już w 1696 roku, rusycystyka, jako taka, stała się dyscypliną akademicką dopiero po drugiej wojnie światowej, co wcale nie oznacza, że mieliśmy i mamy do czynienia z bujnym jej rozwojem, zwłaszcza w warstwie aplikacyjnej. Było i jest wręcz odwrotnie. W szkołach, zwłaszcza państwowych, rosyjski był i jest przedmiotem marginesowym, co więcej, istnieje obawa, że może w ogóle zniknąć z rozkładów zajęć. Kryzys rozpoczął się w latach 30-40. ubiegłego wieku. Ale były także okresy dla języka rosyjskiego korzystne. Zawsze jednak było to związane ze znaczącymi wydarzeniami zachodzącymi w ówczesnym Związku Radzieckim, np. osiągnięcia $\mathrm{w}$ dziedzinie podboju Kosmosu, pierwszy sputnik Ziemi, dojście M. Gorbaczowa do władzy i tzw. "pierestrojka”. Rosyjski zyskiwał na popularności w szkołach i uniwersytetach, a i władze z przychylnością patrzyły i akceptowały taki stan rzeczy. Ale już w latach 70. liczba szkół z językiem rosyjskim zaczęła gwałtownie spadać. Po rozpadzie Związku Radzieckiego ten stan pogłębił się jeszcze bardziej. W wielu szkołach rosyjski zastępowano nawet łaciną. Nieco lepsza jest sytuacja w szkołach prywatnych, ale tych jest w Anglii stosunkowo niewiele.

Nauczyciele-rusycyści narzekają na brak nowoczesnych i atrakcyjnych dla młodzieży materiałów dydaktycznych, m.in. zeszytów ćwiczeń, książek do czytania, tekstów adaptowanych, pomocy wizualnych, oprogramowań komputerowych i internetowych, filmów, komiksów itp.

Na uniwersytetach „koniunktura” na język A. Puszkina też bywa bardzo kapryśna. Tu pierwszorzędne znaczenie mają ukazujące się co kilka lat oficjalne memoranda, określające miejsce danego języka w planach uniwersyteckiego kształcenia. Na przykład w roku 1962, w okresie prosperity radzieckiej kosmonautyki, rekomendowano zwiększenie nauczania języka 
rosyjskiego aż dwudziestopięciokrotnie, za to w 1979 stanowisko oficjalnych władz zmieniło się do tego stopnia, że zamknięto katedry języka rosyjskiego $\mathrm{w}$ ponad dziesięciu uniwersytetach. Decyzje podejmują odpowiednie gremia akademickie, kierując się przede wszystkim rzeczywistym zapotrzebowaniem młodzieży i posiadanym potencjałem naukowym i dydaktycznym. A z tym bywa różnie. W nie tak odległej przeszłości język rosyjski wybierali ci, którzy interesowali się różnymi ideologiami, na przykład marksizmem, socjalizmem, komunizmem, jak również przyszli wojskowi, albo po prostu pasjonaci wszelakiej egzotyki. Powoli jednak zaczęło przybywać tych, którym towarzyszą motywy czysto edukacyjne i poznawcze. Bardzo często rosyjskiego naucza się w zestawieniu z nauką o biznesie, o marketingu, medioznawstwem, technikami komputerowymi itp. A wszystko dlatego, że katedry, które nie przyciągają studentów, nie utrzymują wysokich standardów w zakresie kształcenia i pracy naukowej, mogą być i bywają szybko likwidowane. To zapewne zadecydowało, że osiągnięcia naukowe rusycystów brytyjskich nabrały od pewnego czasu znacznej dynamiki, zwłaszcza w obszarze językoznawstwa porównawczego.

Francja była o wiele bardziej przychylna językowi A. Puszkina, ale i tu nie obyło się bez przeszkód. Pierwsze próby powołania do życia Katedry Języka Rosyjskiego w ówczesnej Szkole Języków Orientalnych (obecnie INALCO) miały miejsce już w 1817 roku. Niestety, nie powiodły się. Dopiero Louis Leger, pierwszy doktor Sorbony w dziedzinie slawistyki (1868), po wielu latach starań, dopiął swego. Sześć lat musiał czekać na zezwolenie francuskiego Ministerstwa Oświaty na rozpoczęcie kursu języka rosyjskiego, które uzyskał w roku akademickim 1874/1875, ale bez żadnych środków finansowych ze strony państwa francuskiego. Takowe otrzymał dopiero po upływie kolejnych dwóch lat, uzyskując zarazem zgodę Ministerstwa na prowadzenie wykładów. „Złoty wiek” dla języka rosyjskiego we Francji przypada dopiero na końcowe lata wieku XIX i wiąże się z nazwiskiem Paula Boyer, wielkiego pasjonata Rosji, kultury i języka rosyjskiego. Ale zawsze było tak, że rusycystyka w kraju nad Sekwaną rozwijała się w zależności od tego, w jaki sposób opinia francuska odbierała Rosję. Pozytywny jej obraz, warunkowany ważkimi wydarzeniami, zwłaszcza polityczno-społecznymi, powodował widoczne ożywienie językiem, literaturą i kulturą rosyjską, zaś obraz negatywny zmieniał się $\mathrm{w}$ mur obojętności, niechęci, a nierzadko i wrogości do wszystkiego, co wiązało się z Rosją.

Aktualnie wspomniane uwarunkowania wzbogaciły się o narastające relacje ekonomiczne z Rosją, turystykę, a także, co nie jest bez znaczenia, o przesłanki natury militarnej. Wiele wskazuje na to, że mimo pozytywnych w sumie impulsów, z wyjątkiem tych militarnych, rusycystyka francuska z roku na rok staje się coraz bardziej chimeryczna i niestabilna. W porównaniu do lat 90. liczba uczących się języka rosyjskiego spadła o połowę, 
zamykane są klasy z językiem rosyjskim, zmniejsza się liczbę godzin i kursów, a wielu rusycystów, z powodu braku możliwości dalszej edukacji $\mathrm{i}$ awansu naukowego, $\mathrm{z}$ powodu braku zatrudnienia, zmienia pracę lub odchodzi z zawodu. Doszło do tego, że ambasador Federacji Rosyjskiej w rozmowie na ten temat $\mathrm{z}$ francuskim ministrem oświaty usłyszał o negatywnym imidżu Rosji, o problemie czeczeńskim, o kryzysie, o braku środków finansowych i o innych problemach, z jakimi borykają się francuskie władze oświatowe. Były uprzejmości, była „pożyteczna wymiana poglądów”, ale istota sprawy pozostała bez zmian. Jest jednak coś, co wyróżnia Francję w jej relacjach z Rosją. To tradycyjna fascynacja Francuzów kulturą i sztuką rosyjską. Ta nad Sekwaną zawsze była w cenie.

Na losy języka rosyjskiego i rusycystyki w Niemczech trzeba spojrzeć $\mathrm{w}$ zupełnie innym wymiarze, ponieważ jest to historia sama w sobie. Wzrastała na wielostronnych podstawach, niczym na solidnych filarach. Filar pierwszy to intensywne od stuleci kontakty handlowe i gospodarcze z Rosją, zapoczątkowane m.in. umową Hanzy niemieckiej z Nowogrodem (1198 r.) i tzw. "Nemecką Słobodą", stworzoną na przedmieściu Moskwy dla niemieckich rzemieślników, majstrów i fachowców z różnych branż. Relacje gospodarcze pomiędzy tymi krajami, kontynuowane przez stulecia $\mathrm{w}$ coraz to nowych dziedzinach, mają miejsce także dziś, ale już na wielką skalę. Drugi to niezwykle silne związki, pakty i układy polityczne pomiędzy Rosją i Niemcami, zawierane na najwyższych szczeblach władzy. Wystarczy wspomnieć Katarzynę II Wielką, Niemkę z pochodzenia, żonę cara Piotra III, a po jego śmierci carycę Rosji, albo wymierzone przeciw Polsce układy rozbiorowe, łącznie z paktem Ribbentrop-Mołotow. Trzeci to niezwykle wysoki poziom nauki niemieckiej i znany od dawna racjonalizm niemiecki, co zawsze przynosiło Niemcom wymierne korzyści i podziw całego świata.

Już w wieku XVII niemieckie Halle stało się głównym ośrodkiem upowszechniania wiedzy o Rosji. Tu powstał specjalny zakład pedagogiczny dla przyszłych krzewicieli oświaty rosyjskiej. Tu też powstała pierwsza biblioteka i drukarnia rosyjska. W Getyndze już w pierwszej połowie XVIII wieku wykładano literaturę rosyjską jako osobny przedmiot akademicki.

Kolejnym impulsem $\mathrm{w}$ rozwoju rusycystyki niemieckiej były wydarzenia związane z kampanią napoleońską 1812 roku. Rosjanie, w pogoni za wojskami Napoleona, witani byli w Niemczech jak oswobodziciele, z zachwytem i wdzięcznością. Rosja stała się bardzo modna, a znajomość języka rosyjskiego bardzo przydatna. Zaowocowało to znaczącymi i licznymi przykładami w obszarze upowszechnienia wiedzy o kulturze rosyjskiej, o języku i literaturze rosyjskiej.

Slawistyka niemiecka stała się dyscypliną naukową w połowie XIX wieku. 15 stycznia 1841 roku król pruski Fryderyk Wilhelm IV wydał rozpo- 
rządzenie, na mocy którego powołano do życia katedry języków i kultur słowiańskich w Berlinie i Wrocławiuํ. Nadmienić jednak trzeba, że próby utworzenia katedry slawistyki w tym ostatnim miały miejsce 10 lat wcześniej, ale nie powiodły się ze względów polityczno-narodowościowych, związanych z Polakami.

Niemiecka slawistyka powstawała w atmosferze wielkiego ożywienia naukowego w Niemczech. Wysoki poziom językoznawstwa teoretycznego i stosowanego miał tu ważne znaczenie. Uczeni tej miary, co Wilhelm von Humboldt, najwybitniejszy językoznawca XIX wieku, F. Bopp - twórca językoznawstwa porównawczego, Jakub Grimm - uważany za ojca językoznawstwa niemieckiego, A. Schleicher - twórca teorii biologicznego naturalizmu i metody historyczno-porównawczej w językoznawstwie, A. Pott - inicjator badań etymologicznych, H. Steinthal, W. Wundt - inicjatorzy psychologizmu językoznawczego, dalej młodogramatycy z Uniwersytetu Lipskiego i wielu innych, znaczyli postęp także $\mathrm{w}$ dziedzinie badań slawistycznych.

Studia rusycystyczne powstawały i rozwijały się $\mathrm{w}$ ramach slawistyki niemieckiej. Początkowo na kilku uniwersytetach, m.in. w Berlinie, Wrocławiu, Lipsku, Monachium, a z czasem w kolejnych. Trzeba jednak pamiętać, że na początku wieku XIX państwa słowiańskie, poza nielicznymi wyjątkami, praktycznie nie istniały na mapach Europy, wchodziły w skład ówczesnych mocarstw. Społecznego "entuzjazmu” dla "ludów słowiańskich" w Niemczech nie było. Jeżeli już, to raczej poniżanie i pogarda. Wyjątki jednak były. Mamy na myśli J. G. Herdera, zaliczanego do czołowych postaci Oświecenia niemieckiego, pisarza, filozofa, pastora, absolwenta Uniwersytetu w Królewcu. Ten niemiecki duchowny, pierwszy spośród XVIII-wiecznych myślicieli, zapisał się w historii poważną refleksją nad losem Słowian, stając $\mathrm{w}$ obronie ich godności i człowieczeństwa, przypisywał im wiele pozytywnych cech - umiłowanie pokoju, pracowitość, gościnność, lagodność, dobroć. Oponował przeciw ich zniewoleniu i poniżaniu praktykami feudalnymi. Jego słowianofilskie poglądy miały ogromny wpływ na rozbudzenie zainteresowania Niemców Słowianami, a co więcej - budziły poczucie narodowe tych ostatnich, budziły nadzieję na lepsze jutro, na własną państwowość, własną podmiotowość i własną kulturę. Były inspiracją dla badań nad słowiańszczyzną $\mathrm{w}$ szerokim tego słowa znaczeniu, impulsem dla niemieckiej slawistyki. Od początku była ona bardzo prężna, o wyraźnej dominacji językoznawczej i cieszyła się dużym uznaniem w świecie naukowym ówczesnej Europy.

Po dojściu Hitlera do władzy następuje okres całkowitego jej wyniszczania. Zapadła noc nie tylko dla slawistyki. Po wojnie proces jej tworzenia od-

\footnotetext{
1 Podaję za: T. W r ó b l e w s k i, Slawistyka w NRD i RFN na tle historycznego rozwoju, Instytut Zachodni, Poznań 1973, s. 70-71.
} 
żył na nowo. Stopniowo powstawały katedry slawistyki, najpierw w Getyndze, w Kolonii, w Bonn, w Hamburgu, następnie w kolejnych ośrodkach akademickich. Kadrę naukową stanowili w większości rusycyści, a studenci slawistyki za główny przedmiot swoich studiów wybierali rusycystykę. W byłej RFN rusycystykę studiowało około 5 tys. studentów (ok. 4 tys. na slawistyce i ponad 1 tys. na rusycystyce). W szkołach gimnazjalnych i tak zwanych Gesamtschule języka rosyjskiego z wyboru uczyło się około 20 tys. uczniów.

W byłej NRD język rosyjski był obowiązkowy na wszystkich poziomach szkolnictwa, stając się $\mathrm{w}$ rzeczywistości narzędziem indoktrynacji politycznej i propagandy komunistycznej. Metodyka jego nauczania sprowadzała się do mechanicznego przenoszenia doświadczeń radzieckich, odnoszących się do rosyjskiego jako języka ojczystego, a rozbudowany do monstrualnych rozmiarów balast ideologii i propagandy czynił to nauczanie całkowicie wypaczonym. Ale próby jego naprawy, a nawet unowocześnienia, były podejmowane. Przykładem mogą być wdrożone w ówczesnej Wyższej Szkole Pedagogicznej w Lipsku badania nad zastosowaniem metody kreatywno-kooperacyjnej, której istota sprowadzała się m.in. do daleko posuniętej współpracy nauczyciela z uczniami, stosowania interesujących wzmocnień motywacyjnych, przyjaznej uczniom organizacji lekcji, doboru tematyki bliskiej uczniowi, a przede wszystkim do orientacji na praktyczne władanie językiem rosyjskim w celach komunikacyjnych. W tej jakże ponurej rzeczywistości były, jak się okazuje, rozwiązania godne najwyższego uznania. To także jedna z osobliwości rusycystyki niemieckiej.

Od pewnego czasu obserwuje się w Niemczech tendencję spadkową liczby uczących się języka rosyjskiego. Jest to widoczne zwłaszcza po obaleniu „Muru Berlińskiego". W 2007 roku ich liczba zmniejszyła się aż czterokrotnie w porównaniu np. do roku 1991 i wynosiła 135 tys. Spada także liczba studentów przyswajających język A. Puszkina w ramach slawistyki bądź rusycystyki. Taki stan rzeczy budzi niepokój niemieckich władz oświatowych. Stało się nawet coś takiego, o czym nikt do tej pory nawet nie pomyślał, a mianowicie przymuszanie uczniów do nauki rosyjskiego wbrew ich woli i wbrew woli ich rodziców. Podobne praktyki odnotowano w 25 gimnazjach na terenie Saksonii, co wywołało oburzenie nie tylko tych najbardziej zainteresowanych - uczniów i ich rodziców, ale również i środków masowego przekazu. Nie na wiele się to zdało, bo i tak władze oświatowe tamtejszego landu utrzymały w mocy decyzję dyrektorów tych gimnazjów. Uciekano do sposobów zgoła zabawnych, choć nie o zabawę tu chodzi, bo oto do klas z językiem rosyjskim dobierano uczniów drogą losowania. A wszystko po to, aby - jak twierdzą niemieckie władze oświatowe - zachować w szkołach Saksonii „językową różnorodność". 
Uczniów niemieckich odstrasza cyrylica i gramatyka rosyjska - deklinacje, koniugacje, formy czasownikowe, a zwłaszcza forma dokonana i niedokonana, przymiotniki, przysłówki, liczebniki itd. A poza tym wciąż pokutujący obraz Rosji jako państwa totalitarnego, postkomunistycznego. Istnieją jednak przesłanki, że obraz ten powoli się zmienia, odpowiednio do zmian zachodzących w samej Rosji.

Włochy to drugi, obok Francji, kraj, gdzie rosyjska kultura i sztuka cieszy się wyjątkowym uznaniem i wielką popularnością. Umiłowanie Włochów do literatury, muzyki, architektury, malarstwa i sztuk wszelakich jest powszechnie znane. Nie dziwi więc wrażliwość na piękno mowy rosyjskiej, piękno poezji, prozy i dramatu w tym języku pisanych. Nieomal każdy z moich włoskich rozmówców w pierwszej kolejności wskazywał na melodyjność języka rosyjskiego. A prof. Eridono Bazzarelli język rosyjski nazywał "językiem duszy": ,jako język duszy ma charakter święty, podobnie jak antyczny język egipski, język sanskrytu, hebrajski, grecki czy łaciński. Jego żywotność i siła wywodzą się z walorów zapisanych w kulturze rosyjskiej i kontaktów, jakie możemy z nią mieć" - konkludował Profesor na jednym z kongresów włoskich rusycystów.

Rusycystyka we Włoszech określana jest jako „,język i literatura rosyjska". Wywodzi się z bogatych tradycji wzajemnego przenikania kultur rosyjskiej i włoskiej $\mathrm{w}$ ich historycznym rozwoju. A początki sięgają wieku XVIII, kiedy to ekspansja kultury włoskiej na ziemie carów rosyjskich stawała się coraz bardziej widoczna. Włoscy architekci, malarze byli szczególnie pożądani, a poeci i pisarze coraz chętniej czytani. To oni propagowali rosyjską kulturę wśród swoich rodaków. Z czasem owe zwiastuny przybierały coraz bardziej konkretne formy. W połowie wieku XIX, we Florencji, ukazała się pierwsza włoska Historia literatury rosyjskiej (Storia della letteratura russa), poezje Puszkina i Lermontowa przetłumaczone na język włoski, a także opracowania historyczno-literackie poświęcone literaturze rosyjskiej.

W roku 1915 w Turynie powstała szkoła języka rosyjskiego (Scuola pratica di lingua russa), ale większego zainteresowania nauką języka rosyjskiego w kraju nad Tybrem nie odnotowano. W dwa lata później (1917) ukazała się pierwsza włoska gramatyka języka rosyjskiego (Grammatica russa teorico-pratica).

Takie były początki slawistki włoskiej, a w jej ramach także rusycystyki. W 1920 roku ukazał się pierwszy numer gazety „Europa Orientalna” („L' Europa Orientale"). Od tego czasu zaczęły pojawiać się kursy języka rosyjskiego w Padwie, Rzymie, we Florencji, w Bolonii, Neapolu, Wenecji, Turynie i Trieście. Daje się zauważyć narastającą działalność naukową slawistów włoskich z akcentem na język i literaturę rosyjską. Rosyjski zajął czołową pozycję wśród innych języków słowiańskich. 
Po II wojnie światowej nauka języka rosyjskiego stała się nieco bardziej popularna w szkolnictwie włoskim, zwłaszcza na poziomie akademickim. Jego wybór przez tamtejszych uczniów i studentów, rzadki co prawda, zawsze był wolny od wszelkich politycznych kontekstów, tym bardziej od bezpośrednich czy pośrednich nacisków. Dla Włochów jest to język niezwykły, bardzo nietypowy, odmienny i trudny.

Pierwszym językiem obcym we włoskich szkołach licealnych jest angielski, drugim najczęściej francuski, rzadziej niemiecki, a trzeci - w trzecim roku nauki - uczniowie wybierają spośród francuskiego, niemieckiego, hiszpańskiego i rosyjskiego. Ciekawostką jest to, że w starszych klasach jedną lekcję w tygodniu prowadzą wspólnie nauczyciel włoski i użytkownik danego języka obcego.

Poza kształceniem szkolnym i uniwersyteckim języka rosyjskiego mogą Włosi uczyć się na kursach językowych, przy czym ich zróżnicowanie jest doprawdy imponujące: „rosyjskie kino", , "rosyjska literatura”, , ,rosyjski język mediów”, "rosyjski w przekładzie”, "konwersacje po rosyjsku”, "rosyjski w biznesie", "rosyjski w turystyce" itp. Zajęcia prowadzone są w weekendy, w dni robocze, także korespondencyjnie i za pośrednictwem Internetu.

Oferta, jak widać, bardzo bogata, nauczanie nowoczesne, nawet bardzo, ale liczby uczących się wcale nie były i nie są imponujące. Na przykład na Uniwersytecie La Sapienza w Rzymie zaledwie około 100 osób to studenci rusycystyki. Bywają takie przypadki, że na wszystkich rocznikach tego kierunku studiuje po kilka osób, a nawet osoby pojedyncze.

Ale to nie przeszkadza włoskim rusycystom, głównie nauczycielom akademickim, w popularyzacji języka i kultury rosyjskiej w różnych środowiskach. Kongresy, sympozja naukowe, seminaria o tematyce rusycystycznej są w tym kraju bardzo częste i mają charakter otwarty. A dorobek naukowy włoskich rusycystów plasuje ich, zdaniem moich rozmówców, w czołówce rusycystyki europejskiej.

Rusycystyka hiszpańska, w porównaniu z angielską, francuską czy niemiecką, należy do najmłodszych, bo liczy sobie zaledwie niecałe 60 lat. Uwarunkowania polityczne, ustrojowe i społeczne, panujące w Hiszpanii przez całe stulecia, nie sprzyjały nawiązywaniu kontaktów z krajami słowiańskimi. A już wojna domowa $\mathrm{w}$ tym kraju i zaangażowanie się Związku Radzieckiego po stronie Republiki, zwycięstwo nacjonalistów i rządy dyktatorskie generała Franco oddaliły ewentualne kontakty na długie lata. Dopiero w drugiej połowie lat pięćdziesiątych (1956) w Państwowym Instytucie Języków Obcych w Madrycie uruchomiono regularny kurs języka rosyjskiego, na który zapisało się 70 osób, a nauczycielami zostali dwaj Rosjanie z tzw. białej emigracji. W kolejnych latach tę formę kształcenia kontynuowano, tym bardziej że liczba słuchaczy systematycznie rosła. 
Dzięki licznej grupie politycznych emigrantów hiszpańskich powracających z całymi rodzinami z byłego ZSRR, którzy po klęsce Republiki musieli uciekać z kraju, rusycystyka hiszpańska nabrała rozpędu na skalę dotychczas nie spotykaną. To w tej grupie znaleźli się ludzie bardzo dobrze znający język rosyjski, literaturę i kulturę rosyjską, a co najważniejsze, zechcieli dzielić się swoimi kompetencjami, upowszechniając z wielką pasją wszystko to, czego nauczyli się na ziemi rosyjskiej. To im rusycystyka hiszpańska zawdzięcza najwięcej. Kursy języka rosyjskiego zaczęły pojawiać się w kolejnych uniwersytetach, m.in w Madrycie, Barcelonie, w Walencji.

Warunki nauczania i tak zwana baza dydaktyczna były więcej niż skromne. Brakowało wykwalifikowanych nauczycieli, podręczników, pomocy naukowych, tekstów adaptowanych dla celów dydaktycznych, czasopism, gazet, bibliotek, zaś grupy słuchaczy na zajęciach liczyły często po 50 osób i więcej. Nie brakowało jedynie zaangażowania i serca do pracy. Stopniowo zaczęły pojawiać się tłumaczone na hiszpański utwory pisarzy rosyjskich - L. Tołstoja, A. Czechowa, I. Turgieniewa, A. Tołstoja, M. Szołochowa, L. Leonowa, M. Bułhakowa, M. Zoszczenki i innych. Wcześniej ukazywały się nieliczne przekłady, ale z języka francuskiego. Przybywało podręczników akademickich, opracowań historycznoliterackich i językoznawczych dla uczniów i studentów hiszpańskich.

Obecnie w uniwersytetach hiszpańskich (Madryt, Barcelona, Grenada, Bilbao) prowadzone jest nauczanie języka rosyjskiego o profilu filologicznym i tłumaczeniowym. Ale rosyjski wciąż uważany jest za język egzotyczny i wybierany rzadko, jako trzeci język obcy.

Profesor Maria Sanchez Puig z Madryckiego Uniwersytetu, czołowa postać w rusycystyce hiszpańskiej, autorka fundamentalnych prac naukowych, wybitna tłumaczka literatury rosyjskiej na język hiszpański, doktor honoris causa Rosyjskiej Akademii Nauk, mówiąc w swoich publikowanych wykładach o dziejach rusycystyki hiszpańskiej, przywołuje fakty świadczące o zawiłościach, które mogą zdumiewać każdego, nie tylko rusycystę. Oto niektóre z nich:

- w roku 1972 w Madryckim Autonomicznym Uniwersytecie powołano do życia Instytut Wschodu i Afrykanistyki, a w jego ramach sekcję slawistyki z językami rosyjskim, polskim i bułgarskim. Przygotowano programy i plany pięcioletnich studiów, w charakterze wykładowców zaproszono specjalistów ze Związku Radzieckiego, Polski i Bułgarii, stworzono odpowiednią bazę dydaktyczną, m.in. bibliotekę, i rozpoczęto zajęcia. Wszystko było w najlepszym porządku do momentu, kiedy pierwsi absolwenci mieli otrzymać dyplomy ukończenia studiów. Wówczas okazało się, że powołany Instytut nie posiadał odpowiednich uprawnień, nadawanych uczelniom wyższym przez hiszpańskie Ministerstwo Oświaty. Wybuchł skandal. Absolwenci, zamiast dyplomów, otrzymali nic nie znaczące zaświadczenia. 
Sprawę szybko zatuszowano, "Instytut” zamknięto, język rosyjski stał się znowu przedmiotem fakultatywnym, a polski i bułgarski zlikwidowano. To był rok 1980! Trzeba było kolejnych dziesięciu lat, aby powstał w Madryckim Uniwersytecie Wydział Filologii Słowiańskiej i już bez przeszkód formalnych i niespodzianek mógł rozpocząć działalność. W krótkim czasie podobne wydziały powstały na uniwersytetach w Grenadzie i Barcelonie, ale zainteresowanie językami słowiańskimi, w tym językiem rosyjskim, okazuje się być znikome - 10-12 studentów każdego roku.

- osobliwość kolejna dotyczy poziomu kształcenia. Okazuje się, że absolwenci slawistyki - rusycyści - nie są w stanie sprostać ani wymaganiom stawianym nauczycielom języka rosyjskiego, ani wymaganiom stawianym pracownikom firm z udziałem kapitału rosyjskiego, bo po prostu nie znają języka w stopniu wystarczającym. Nie potrafią nawet przeprowadzić w sposób poprawny rozmowy telefonicznej, ani też prowadzić służbowej korespondencji biznesowej, nie mówiąc już o kwalifikacjach, jakimi powinien dysponować tłumacz. Ale za to mogą, o zgrozo (!), robić karierę naukową. Wystarczy dostać się na aspiranturę, co wcale nie jest takie trudne, uzyskać odpowiednią liczbę punktów za różne przedmioty, niekoniecznie z zakresu swojej specjalizacji, pod kierunkiem profesora, który może nie mieć nic wspólnego z językiem rosyjskim, ba, może nawet nie znać alfabetu rosyjskiego, napisać pracę doktorską po hiszpańsku, obronić ją również w języku hiszpańskim i otrzymać tytuł doktora filologii słowiańskiej. Mając takie „kwalifikacje”, może bez przeszkód „nauczać" języka rosyjskiego. W prawie hiszpańskim nie ma bowiem zdefiniowanych kryteriów, jakim powinien sprostać absolwent studiów slawistycznych, w tym rusycystycznych. Nie trzeba być specjalistą-rusycystą, aby „nauczać” języka rosyjskiego i literatury rosyjskiej. W ten sposób szeregi hiszpańskich rusycystów mogą zasilać i zasilają np. iberyści, angliści, germaniści, arabiści i inni. Ale sytuacja odwrotna, tzn. aby rusycysta stał się anglistą i chciał „nauczać” angielskiego, nie jest już, w świetle obowiązujących w Hiszpanii przepisów, dopuszczalna.

Słuchając Pani Profesor, nie mogliśmy oprzeć się zdumieniu połączonemu ze współczuciem dla rusycystów hiszpańskich z prawdziwego zdarzenia, posiadających rzeczywiste, a nie tylko formalne, kwalifikacje do nauczania języka i literatury rosyjskiej. Trudno bowiem nadążyć za zawiłościami, z jakimi muszą borykać się nasi hiszpańscy koledzy z powodu braku tak oczywistych uregulowań prawnych związanych $\mathrm{z}$ dziedziną, którą uprawiają z myślą o przybliżeniu swoim rodakom języka i kultury jednego z największych krajów świata.

Są jeszcze inne, bardziej uniwersalne, osobliwości w rusycystyce, nie tylko zachodnioeuropejskiej. Warto wskazać chociażby na dwie z nich.

Pierwsza dotyczy odróżniania rusycystyki jako dziedziny naukowej od tego, co nazwać można propagandą rusycystyczną. Ta ostatnia zamula, nie- 
stety, tę pierwszą coraz bardziej. Budzi to niepokój wszystkich moich rozmówców z krajów Europy Zachodniej. Odnosi się wrażenie, że mamy coraz więcej imprez towarzysko-rozrywkowych i propagandowych pogadanek, a coraz mniej nauki. Zanikają badania eksperymentalne w obszarze glottodydaktyki rusycystycznej, brakuje analiz porównawczych żywego języka rosyjskiego z językami krajów, w których się go naucza, analiz przygotowanych w sposób przystępny i atrakcyjny dla uczącej się młodzieży. Brakuje opisów języków specjalistycznych dla celów dydaktycznych z wykorzystaniem nowych technologii informatycznych. Podręczniki do nauki gramatyki rosyjskiej tkwią w XIX-wiecznej tradycji nauczania formalnego, a językoznawcy wydają się nie dostrzegać wieku XXI i zmian zachodzących w otaczającym nas świecie komunikacji językowej. Brakuje aplikacyjnych odniesień do gramatyki tekstu i nowoczesnych teorii językoznawczych. Brakuje pomysłowo adaptowanych tekstów literackich dla celów dydaktycznych, zwłaszcza z literatury współczesnej, brakuje materiałów pomocniczych w postaci chociażby wyciągów prasowych do nauczania konwersacji i żywego języka rosyjskiego. Brakuje wielu rzeczy, nie brakuje natomiast narzekań na to, że uczniowie i studenci coraz rzadziej wybierają język rosyjski i rusycystykę jako przedmiot studiów. Ot, taka „drobna” subtelność.

Osobliwość druga wiąże się z wewnętrznym rozwarstwieniem rusycystyki na rusycystykę „urzędową", „oficjalną", ,prorosyjską" i rusycystykę "niezależną", „wolną" i „demokratyczną". Są to podziały nieoficjalne, ukryte, ale są. Spotkałem rusycystów, którzy, jak powiadają, "nie splamili się" udziałem w żadnym kongresie MAPRJAL ${ }^{2}$, ponieważ traktują je jako imprezy wybitnie propagandowe, nie mające nic wspólnego z kongresami naukowymi. Samą zaś organizację traktują jako pozostałość postsowiecką, zdominowaną przez przedstawicieli Rosji, uprawiającą coś $\mathrm{w}$ rodzaju imperializmu językowego w skali światowej, pozostałość, którą powinno się, ich zdaniem, dawno rozwiązać.

"To tylko niektóre meandry naszej zachodnioeuropejskiej rusycystki" - mówi jeden z moich rozmówców. I dodaje: „Myślę, że w Polsce i w pozostałych krajach byłego bloku radzieckiego jest ich o wiele więcej, czyż nie?". Pozostawimy to pytanie bez odpowiedzi, przynajmniej na razie.

\footnotetext{
${ }^{2}$ Międzynarodowe Stowarzyszenie Wykładowców Języka Rosyjskiego i Literatury.
} 
